\title{
Causal relationship between banking system development and real estate market
}

\author{
My-Linh Thi Nguyena, Pham Thi Thanh Xuan ${ }^{b}$ and Toan Ngoc Buic*
}

\begin{abstract}
${ }^{a}$ Associate Professor, Faculty of Finance and Banking, University of Finance-Marketing (UFM), Vietnam
${ }^{b}$ Lecturer, Faculty of Finance and Banking, University of Finance - Marketing (UFM), Vietnam

${ }^{c}$ Lecturer, Faculty of Finance and Banking, Industrial University of Ho Chi Minh City (IUH), Vietnam

\section{H R O N I C L E}

Article history:

Received: July 82019

Received in revised format: July 9

2019

Accepted: August 11, 2019

Available online:

August 12, 2019

Keywords:

Banking system

Real estate market

\section{A B S T R A C T}

This paper analyzes the causal relationship between the banking system development and the real estate market in Vietnam from 2004:Q3 to 2018:Q4, with the use of the autoregressive distributed lag (ARDL) model as the analysis method. In Vietnam, there is no empirical study on this issue. Therefore, the paper is the first empirical evidence for the relationship between the banking system development and the real estate market in Vietnam. The research results show that the banking system development (measured through the domestic credit to the private sector) and the real estate market had a positive causal relationship in both short and long terms. In addition, the paper found a statistically significant impact of the global financial crisis on the banking system development and the real estate market in Vietnam, which is a new discovery compared with previous studies.
\end{abstract}

Financial crisis

$A R D L$

Vietnam
O 2020 by the authors; licensee Growing Science, Canada

\section{Introduction}

The bubble boom in the real estate market combined with subprime mortgage lending was the main reason for the financial crisis in the United States at the end of 2007 (Tsai, 2015; Zhang et al., 2016; Bahmani-Oskooee \& Ghodsi, 2018). The financial crisis in the United States had negative impacts on the global economy (Zhang et al., 2016). Therefore, since the emergence of this financial crisis, researchers and policy makers have paid more attention to the relationship between the banking system development and the real estate market. The banking system development and the real estate market may have a two-way causal relationship. Indeed, the banking system development affects the real estate market through the wealth effect (Gimeno \& Martínez-Carrascal, 2010; Che et al., 2011). On the other hand, the impact of the real estate market on the banking system development can be explained through the credit effect (Anundsen \& Jansen, 2013). However, the relationship between the banking system development and the real estate market still has received significant amount of debates. For example, some researchers like Gimeno and Martínez-Carrascal (2010), Hott (2011), Ibrahim and Law (2014), Huang et al. (2015), Shen et al. (2016), and Lim (2018) have argued that the banking system development and the real estate market have a positive relationship. Meanwhile, Yunus (2012), Wen and He (2015) believe that the

\footnotetext{
* Corresponding author.

E-mail address: buingoctoan@iuh.edu.vn (T. N. Bui) 
banking system development has a negative impact on the real estate market. Moreover, the studies on this issue mainly focused on developed countries, and there is a lack of empirical studies in developing countries like Vietnam. In addition, no research has analyzed the role of the global financial crisis in the relationship between the banking system development and the real estate market.

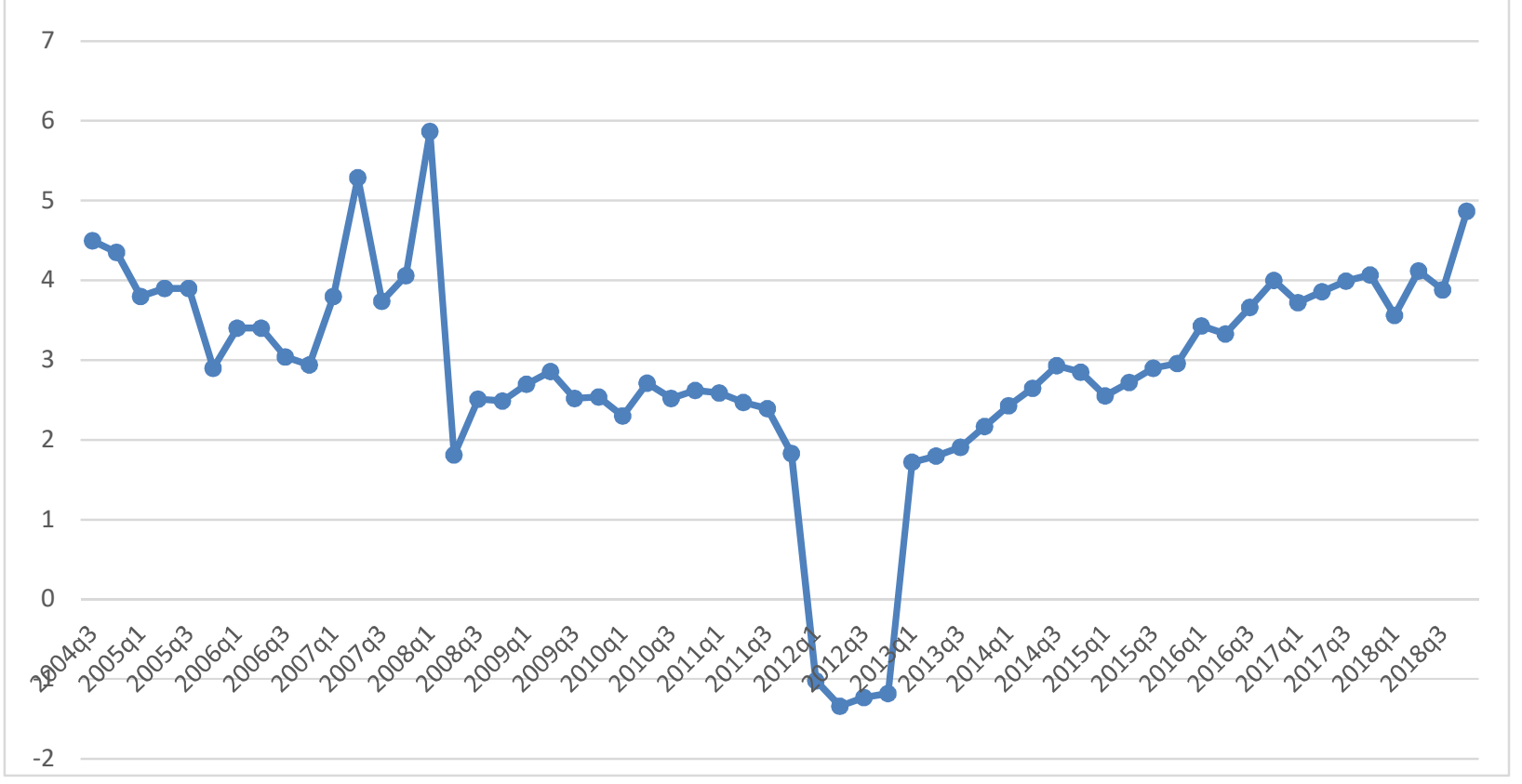

Fig. 1. Growth of the real estate market (REM) in Vietnam (2004:Q3-2018:Q4)

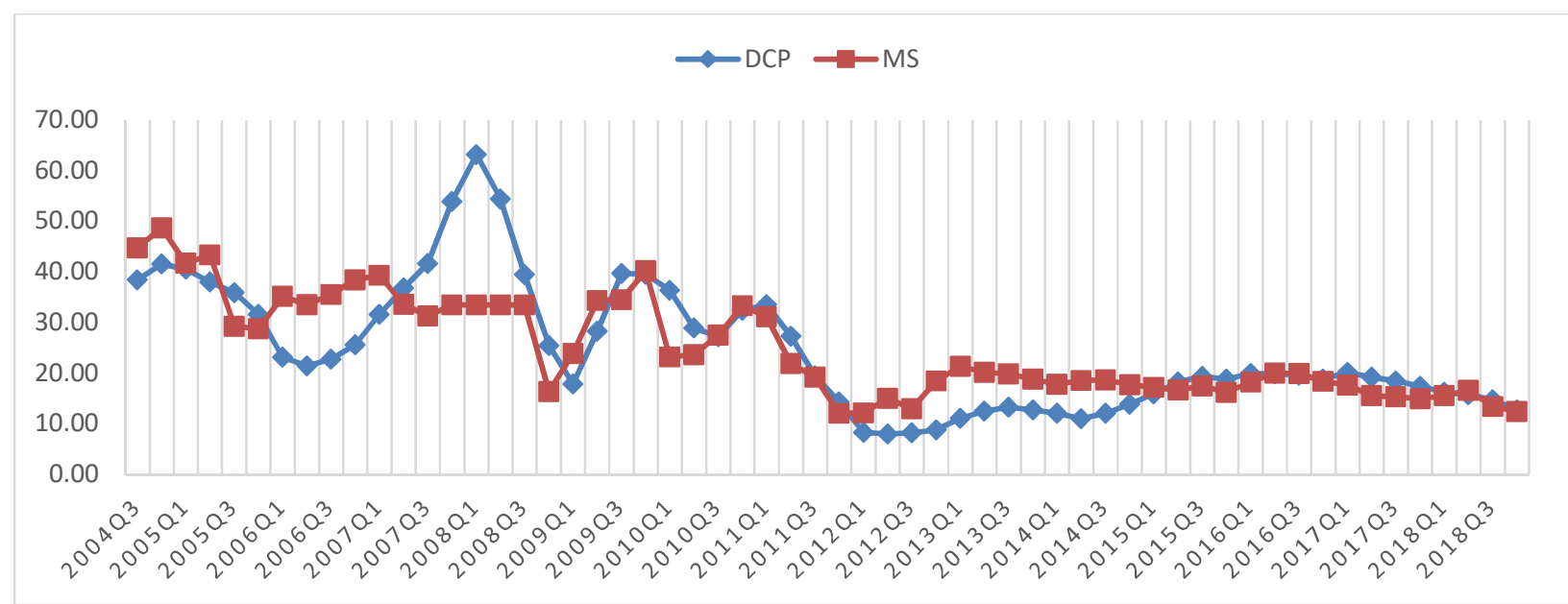

Fig. 2. Growth of the domestic credit to the private sector (DCP) and the money supply (MS) in Vietnam (2004: Q3-2018:Q4)

In Vietnam, the banking system and the real estate market are relatively young. However, the banking system and the real estate market have achieved certain developments and demonstrated an important position for the economy. In particular, the banking system plays a key role in providing credit for Vietnam's financial market, where the financial resources in enterprises are formed mainly from bank credit (Batten \& Vo, 2016). In 2007, Vietnam became an official member of the World Trade Organization (WTO). With these positive signals, production and business activities have been expanded, and Vietnam's economy has grown well and achieved many great achievements. Therefore, the banking system 
in Vietnam has developed impressively with the growth of the domestic credit to the private sector reaching the highest value in the first quarter of 2008 (the growth of $63.21 \%$ compared with the same period of the previous year). At the same time, the real estate market also achieved the highest growth value (the growth of $5.87 \%$ compared with the same period of the previous year). However, it was right after the first quarter of 2008 that the real estate market in Vietnam decreased sharply due to the negative impacts of the global financial crisis and the difficulties of the national economy. The difficulties of the real estate market in Vietnam had significant impacts on the Vietnamese banking system. Under such difficulties, the State Bank implemented a more prudent monetary policy to stabilize the economy. Therefore, the growth of the domestic credit to the private sector and the money supply declined and maintained the lowest value for the period of 2011-2012. In addition, this led to the sharp decrease in the real estate market in late 2012 due to the difficulties in accessing capital from banks. Recently, the banking system has developed steadily, creating a driving force for the recovery of the real estate market to recover and advance again. In view of that, it can be said that the banking system development and the real estate market have a close relationship. However, in Vietnam, there are no empirical studies on this issue. With this paper, the research team will overcome the limitations of previous studies, and create the first empirical evidence in Vietnam, thus bringing practical and meaningful value to Vietnam.

\section{Literature Review}

The relationship between the banking system development and the real estate market has been of interest for many researchers, especially since the global financial crisis in late 2007. The impact of the banking system development on the real estate market can be explained through the wealth effect (Che et al., 2011). Accordingly, the banking system development can help increase the assets of households and enterprises, which will accelerate the amount of investment in the real estate market, contributing to the development of the real estate market. On the other hand, the real estate market affects the banking system development through the credit effect (Anundsen \& Jansen, 2013). The credit effect indicates that as the real estate market grows, real estate holders will become more profitable because the increase in the asset value helps them easily access loans and real estate mortgages for bank loans, and the increase in the credit provided by the banking industry promotes the profitability and the development of the banking system. As a result, it can be said that a relationship exists between the banking system development and the real estate market through the wealth effect and the credit effect. In particular, the banking system development is mainly measured through the growth of the bank credit outstanding balance and the money supply.

Indeed, Liang and Cao (2007) found the positive impact of the bank credit outstanding balance, the economic growth and the interest rate on the Chinese real estate market for the period from 1999:Q1 to 2006:Q2. In another study, Gimeno and Martínez-Carrascal (2010) argued that there was a positive longterm relationship between the bank credit outstanding balance and the real estate market in Spain. In the same view, Hott (2011) also found a positive relationship between the bank credit outstanding balance and the real estate market in the United States and the United Kingdom. Moreover, Hott (2011) also claimed that the banking system affected the crisis in the real estate market through the provision of credit capital for the real estate market. In Malaysia, Ibrahim and Law (2014) showed that the bank credit outstanding balance had a positive relationship with the real estate market in both short and long term, in which the impact of the bank credit outstanding balance on the real estate market was greater than the impact of the real estate market on the bank credit outstanding balance. In addition, Ibrahim and Law (2014) also found a negative impact of the interest rate on the real estate market. In another study, Huang et al. (2015) argued that the bank credit outstanding balance had a positive impact on the real estate market in 35 Chinese cities during the post-financial crisis (after the year 2008). On the other hand, Huang et al. (2015) also found the positive impact of the real estate market and the interest rate on the credit outstanding balance during the period of the study (1999-2012). In China, Shen et al. (2016) found a positive relationship between the ratio of the domestic credit to the private sector to gross domestic product (GDP) and the real estate market. In particular, the impact of the real estate market on the ratio 
of the domestic credit to the private sector to GDP is stronger than the impact of the ratio of the domestic credit to the private sector to GDP on the real estate market. In addition, Zhao et al. (2017) believed that the crisis in the Chinese real estate market led to the decrease in the real estate prices and the bank liquidity (due to the fact that the real estate loans were unpaid and the value of collateral is not enough to pay off loans), causing the financial crisis. Furthermore, Zhao et al. (2017) also presumed that the increase in the money supply and the bank credit outstanding balance results in more real estate investments, leading to the increase in the real estate prices. In Lithuania, Gasparenienè et al. (2017) found the positive impact of the bank credit outstanding balance on the real estate market (the variation of housing price level was explained by 79.03\%). In addition, Gasparénienè et al. (2017) also assumed that the real estate market is negatively affected by the economic growth and positively affected by the interest rate and the consumer price index. Recently, Lim (2018) found a positive relationship between the ratio of the domestic credit to the private sector to GDP and the real estate market in 54 countries. Most of the previous studies have suggested that there is a positive relationship between the banking system development and the real estate market. However, some views argued that the banking system development has a negative impact on the real estate market. This shows that when the amount of money provided by the banking system for the economy (including the real estate market) increases too high, it can create a bubble phenomenon in the real estate market, resulting in the fact that the real estate market is in danger of recession in the next periods. Indeed, when analyzing the data of 10 developed countries in North America, Europe, Australia and Asia, Yunus (2012) showed that the money supply has a positive impact on the real estate market in the short term, but this impact is negative in the long term. In another study, Wen and He (2015) asserted that the money supply has a positive impact on the real estate market in China in the short term, but then this impact is negative in the long term.

\section{Data and Methodology}

\subsection{Data Collection}

The research data were collected quarterly during the period from 2004:Q3 to 2018:Q4. The data on the real estate market growth were collected from the General Statistics Office of Vietnam (GSO). The data on the banking system development were collected from the source of the State Bank of Vietnam (SBV) and the International Monetary Fund (IMF). The data on the control variables representing the stock market development were collected from the source of the State Securities Commission (SSC). For the control variables representing macroeconomics, the data on the economic growth and the consumer price index were collected from the source of the General Statistics Office of Vietnam (GSO), and the data on interest rate were collected from the International Monetary Fund (IMF).

\subsection{Methodology}

The paper uses the autoregression distributed lag (ARDL) model to analyze the relationship between the banking system development and the real estate market in Vietnam. The use of ARDL model is based on the research of Liang and Cao (2007). On the other hand, the ARDL model is appropriate to the empirical research using time series data in the case that the number of observations is small and the data series do not stop at the same level (Pesaran et al., 2001). This particular feature is quite suitable for Vietnam.

The variable measuring the real estate market: The study measures the real estate market through the index of the real estate market growth announced by the General Statistics Office of Vietnam (GSO). The real estate market growth focuses on business activities in the real estate market, including three main areas: commerce, office leasing or housing rental, consultancy (brokerage). This index was also used in the study by Lambertini et al. (2017).

The variable measuring the banking system development: The paper uses the index of the domestic credit to the private sector (the domestic credit to the private sector to GDP) and the money supply (the money 
supply (M2) to GDP) to measure the banking system development. The index of the domestic credit to the private sector was used in the studies by Shen et al. (2016), and Lim (2018). The money supply index was used in the studies by Yunus (2012), Wen and He (2015), and Zhao et al. (2017).

The control variable representing the stock market development: The paper employs the control variable representing the stock market development in the research model to test the impact of the banking system development on the real estate market in Vietnam since the stock market development plays an important role in the real estate market. This issue was mentioned in the studies by Markowitz (1952), Kapopoulos and Siokis (2005), Ibrahim (2010), Ding et al. (2014), Lean and Smyth (2014). The paper measures the stock market development through Vietnam stock index (the logarithm of Vietnam stock index), the stock market efficiency (the value of traded stocks to the market capitalization value) and the net transaction value of foreign investors (the net transaction value of foreign investors to the transaction value in the stock market). The stock index and the stock market efficiency are two important indicators in the composite index of the stock market development mentioned by Pradhan et al. (2014). In addition, the index of the net transaction value of foreign investors was added to the study because this index is one of the indicators reflecting the international integration level of the stock market (Bolanos et al., 2015). Simultaneously, foreign investors also play an important role in the stock market development as well as in Vietnam's real estate market in the context of international economic integration.

The control variable representing macroeconomics: The control variables representing macroeconomics used in the study include economic growth, consumer price index, interest rate (lending interest rate to deposit interest rate) and financial crisis. The research team used the variables of economic growth and consumer price index based on the study by Liang and Cao (2007), Gasparenniene et al. (2017). The variable of the interest rate was also mentioned in the study by Liang and Cao (2007), Gasparenienè et al. (2017), but was measured through lending interest rate. In this study, the research team measured interest rate through the ratio of lending interest rate to deposit interest rate. The research team expected that the ratio of lending interest rate to deposit interest rate will play an important role in the relationship between the banking system development and the real estate market, because if this ratio is large, it will reflect the increase in the main income (from lending) of the banking system. This ratio is also an early warning indicator of the crisis in the banking system (Kaminsky \& Reinhart, 1999; Godstein et al., 2000). In addition, the reality shows that the global financial crisis plays a significant role in the relationship between the banking system development and the real estate market. This was also mentioned in the study by Huang et al. (2015). Therefore, the research team put the financial crisis factor into the study. The global financial crisis began in August 2007 (Hui \& Chan, 2014) and lasted until March 2013 (Cayon et al., 2017). Accordingly, the financial crisis is measured through the dummy variable: the financial crisis will receive a value of 1 for the period of the global financial crisis (from the third quarter of 2007 to the first quarter of 2013) and receive the value of 0 for the remaining periods.

- The impact of the banking system development on the real estate market in Vietnam

+ Long-term impact:

+ Short-term impact:

$$
R E M_{t}=\beta_{10}+\beta_{11} B S D_{t}+\beta_{12} S M D_{t}+\beta_{13} C V_{t}+v_{1 t}
$$

$$
\Delta R E M_{t}=\alpha_{10}+\sum_{j=1}^{k} \lambda_{11} \Delta R E M_{t-j}+\sum_{j=0}^{k} \lambda_{12} \Delta B S D_{t-j}+\sum_{j=0}^{k} \lambda_{13} \Delta S M D_{t-j}+\sum_{j=0}^{k} \lambda_{14} C V_{t-j}+\phi_{1} E C M_{t-1}+\varepsilon_{1 t}
$$

- The impact of the real estate market on the banking system development in Vietnam + Long-term impact:

+ Short-term impact:

$$
\mathrm{BSD}_{\mathrm{t}}=\beta_{20}+\beta_{21} \mathrm{REM}_{\mathrm{t}}+\beta_{22} \mathrm{CV}_{\mathrm{t}}+\mathrm{v}_{2 \mathrm{t}}
$$

$$
\Delta B S D_{t}=\alpha_{20}+\sum_{j=1}^{k} \lambda_{21} \Delta B S D_{t-j}+\sum_{j=0}^{k} \lambda_{22} \Delta R E M_{t-j}+\sum_{j=0}^{k} \lambda_{23} \Delta C V_{t-j}+\phi_{2} E C M_{t-1}+\varepsilon_{2 t}
$$

where: 
The variable measuring the real estate market: real estate market growth (REM). This index is calculated as a quarterly growth rate compared to the previous year.

The variables measuring the banking system development (BSD) include domestic credit to the private sector (DCP) and money supply (MS). These two indices are calculated as quarterly growth rates compared to the previous year.

The control variables representing the stock market development (SMD): stock index (VNI), stock market efficiency (SME) and net transaction value of foreign investors (FI). These three indices are calculated on a quarterly basis.

The control variables representing macroeconomics $(\mathrm{CV})$ : economic growth (GDP), consumer price index (CPI), interest rate (IR), financial crisis (FC).

Error correction mode (ECM)

\section{Empirical Results and discussion}

\subsection{Unit root test}

The paper conducted a test of the stationarity of the data series through testing the stationarity proposed by Dickey and Fuller (1979), with the hypothesis $\mathrm{H}_{0}$ : the data series is not stationary.

Table 1

Results of unit root tests

\begin{tabular}{lcc}
\hline Variable & $\mathrm{I}(0)$ & $\mathrm{I}(1)$ \\
\hline Real estate market growth (REM) & 0.1167 & $0.0000^{* * *}$ \\
Domestic credit to the private sector (DCP) & 0.4706 & $0.0024^{* * *}$ \\
Money supply (MS) & 0.1478 & $0.0000^{* * *}$ \\
Stock index (VNI) & 0.3334 & $0.0000^{* * *}$ \\
Stock market efficiency (SME) & $0.0433^{* *}$ & $0.0000^{* * *}$ \\
Net transaction value of foreign investors (FI) & $0.0002^{* * *}$ & $0.0000^{* * *}$ \\
Economic growth (GDP) & $0.0449^{* *}$ & $0.0000^{* * *}$ \\
Consumer price index (CPI) & 0.4612 & $0.0013^{* * *}$ \\
Interest rate (IR) & 0.1591 & $0.0000^{* * *}$ \\
\hline
\end{tabular}

Note: ** and $* * *$ indicate significance at the $5 \%$ and $1 \%$ level, respectively.

Table 1 shows that the variables of stock market efficiency (SME), net transaction value of foreign investors (FI) and economic growth (GDP) stop at the original data series I(0). Meanwhile, the remaining data series stop at the differential series I(1) at the $1 \%$ significance level. Therefore, these data series are suitable for analysis in accordance with the ARDL model because Pesaran et al. (2001) argued that if the data series do not stop at the same level, the ARDL model is the most appropriate to empirical studies.

\subsection{Cointegration test}

The paper identifies the lag length of variables in the ARDL model through the Bayesian Information Criterion (BIC). In addition, the paper also uses the bound test method proposed by Pesaran et al. (2001) to test the cointegration between data series. Hypothesis $\mathrm{H}_{0}$ : there is no cointegration relationship between the data series (no level relationship). 
Table 2

Results of cointegration test

Model 1: The impact of the banking system development (BSD) on the real estate market (REM) $\mathrm{F}_{1}=5.885$

\begin{tabular}{|c|c|c|c|c|c|c|c|c|}
\hline & \multicolumn{2}{|c|}{$10 \%$} & \multicolumn{2}{|c|}{$5 \%$} & \multicolumn{2}{|c|}{$1 \%$} & \multicolumn{2}{|c|}{$\mathrm{p}$-value } \\
\hline & $\mathrm{I}(0)$ & $\mathrm{I}(1)$ & $\mathrm{I}(0)$ & $\mathrm{I}(1)$ & $\mathrm{I}(0)$ & $\mathrm{I}(1)$ & $\mathrm{I}(0)$ & $\mathrm{I}(1)$ \\
\hline $\mathrm{F}_{1}$ & 2.049 & 3.328 & 2.402 & 3.820 & 3.223 & 4.955 & $0.000^{* * *}$ & $0.003^{* * *}$ \\
\hline \multicolumn{9}{|c|}{ Model 2: The impact of the real estate market (REM) on the domestic credit to the private sector (DCP) $\mathrm{F}_{2}=6.986$} \\
\hline & \multicolumn{2}{|c|}{$10 \%$} & \multicolumn{2}{|c|}{$5 \%$} & \multicolumn{2}{|c|}{$1 \%$} & \multicolumn{2}{|c|}{$\mathrm{p}$-value } \\
\hline & $\mathrm{I}(0)$ & $\mathrm{I}(1)$ & $\mathrm{I}(0)$ & $\mathrm{I}(1)$ & $\mathrm{I}(0)$ & $\mathrm{I}(1)$ & $\mathrm{I}(0)$ & $\mathrm{I}(1)$ \\
\hline $\mathrm{F}_{2}$ & 2.388 & 3.614 & 2.843 & 4.203 & 3.888 & 5.541 & $0.000^{* * *}$ & $0.002^{* * *}$ \\
\hline \multicolumn{9}{|c|}{ Model 3: The impact of the real estate market (REM) on the money supply (MS) $F_{3}=1.766$} \\
\hline & \multicolumn{2}{|c|}{$10 \%$} & \multicolumn{2}{|c|}{$5 \%$} & \multicolumn{2}{|c|}{$1 \%$} & \multicolumn{2}{|c|}{ p-value } \\
\hline & $\mathrm{I}(0)$ & $\mathrm{I}(1)$ & $\mathrm{I}(0)$ & $\mathrm{I}(1)$ & $\mathrm{I}(0)$ & $\mathrm{I}(1)$ & $\mathrm{I}(0)$ & $\mathrm{I}(1)$ \\
\hline $\mathrm{F}_{3}$ & 2.366 & 3.637 & 2.822 & 4.241 & 3.877 & 5.621 & 0.240 & 0.620 \\
\hline
\end{tabular}

Note: $* * *$ indicates significance at the $1 \%$ level.

Table 2 shows that $\mathrm{F}$ is greater than the upper-bound critical value $\mathrm{I}(1)$ at the $1 \%$ significance level (models 1 and 2). Therefore, there is a cointegration relationship between the data series in models 1 and 2 with the $1 \%$ significance level. However, there is no cointegration relationship between the data series (no level relationship) in model 3. Thus, the paper uses the ARDL model to analyze the relationship between the banking system development and the real estate market through models 1 and 2 .

\subsection{Results of coefficient estimation}

The analysis results regarding the relationship between the banking system development and the real estate market according to the ARDL model are as follows:

Table 3

The estimated long-run coefficient results

\begin{tabular}{|c|c|c|c|c|}
\hline \multirow[b]{2}{*}{ Variable } & \multicolumn{2}{|c|}{$\begin{array}{c}\text { Model (1) } \\
\text { (dependent variable: REM) }\end{array}$} & \multicolumn{2}{|c|}{$\begin{array}{c}\text { Model (2) } \\
\text { (dependent variable: DCP) }\end{array}$} \\
\hline & Coef. & Prob. & Coef. & Prob. \\
\hline REM & & & 7.429 & $0.000^{* * *}$ \\
\hline DCP & 0.101 & $0.000^{* * *}$ & & \\
\hline MS & 0.050 & 0.158 & & \\
\hline VNI & 0.036 & $0.039^{* *}$ & & \\
\hline SME & -0.647 & 0.307 & & \\
\hline FI & -0.161 & $0.005^{* * *}$ & & \\
\hline GDP & -0.096 & 0.575 & 4.021 & $0.004^{* * *}$ \\
\hline CPI & -0.051 & 0.303 & 0.697 & 0.155 \\
\hline IR & 0.029 & $0.086^{*}$ & -0.035 & 0.816 \\
\hline $\mathrm{FC}$ & -0.012 & $0.033^{* *}$ & 0.148 & $0.019^{* * *}$ \\
\hline
\end{tabular}

Note: *,**and $* * *$ indicate significance at the $10 \%, 5 \%$ and $1 \%$ level, respectively.

Table 4

Estimated short-run error correction model

\begin{tabular}{|c|c|c|c|c|}
\hline \multirow[t]{2}{*}{ Variable } & \multicolumn{2}{|c|}{$\begin{array}{c}\text { Model (1) } \\
\text { (dependent variable: } \triangle \text { REM) }\end{array}$} & \multicolumn{2}{|c|}{$\begin{array}{c}\text { Model (2) } \\
\text { (dependent variable: } \triangle \mathrm{DCP} \text { ) }\end{array}$} \\
\hline & Coef. & Prob. & Coef. & Prob. \\
\hline$\triangle \mathrm{REM}$ & & & 2.019 & $0.000^{* * * *}$ \\
\hline$\triangle \mathrm{DCP}$ & 0.068 & $0.059^{*}$ & & \\
\hline$\triangle \mathrm{DCP}(-1)$ & -0.095 & $0.004^{* * *}$ & 0.574 & $0.000^{* * *}$ \\
\hline$\triangle \mathrm{MS}$ & 0.034 & 0.122 & & \\
\hline$\triangle \mathrm{VNI}$ & 0.025 & $0.042^{* *}$ & & \\
\hline$\triangle \mathrm{SME}$ & -0.438 & 0.295 & & \\
\hline$\triangle \mathrm{FI}$ & -0.109 & $0.001^{* * *}$ & & \\
\hline$\triangle \mathrm{GDP}$ & -0.065 & 0.574 & 1.093 & $0.007^{* * *}$ \\
\hline$\triangle \mathrm{CPI}$ & 0.064 & 0.208 & 0.047 & 0.835 \\
\hline$\triangle \mathrm{CPI}(-1)$ & & & -0.413 & $0.049^{* *}$ \\
\hline$\triangle \mathrm{CPI}(-2)$ & & & -0.658 & $0.002^{* * *}$ \\
\hline$\triangle I R$ & 0.019 & $0.062^{*}$ & -0.010 & 0.818 \\
\hline$\triangle \mathrm{FC}$ & -0.008 & $0.062^{*}$ & 0.040 & $0.008^{* * *}$ \\
\hline $\operatorname{ECM}(-1)$ & -0.676 & $0.000^{* * *}$ & -0.272 & $0.000^{* * * *}$ \\
\hline Constant & -0.085 & $0.009^{* * *}$ & -0.085 & 0.162 \\
\hline R-squared & \multicolumn{2}{|c|}{$63.35 \%$} & \multicolumn{2}{|c|}{$79.74 \%$} \\
\hline White's test & \multicolumn{2}{|c|}{ Prob $>$ chi $2=0.4371$} & \multicolumn{2}{|c|}{ Prob $>$ chi $2=0.4365$} \\
\hline Breusch-Godfrey LM test & \multicolumn{2}{|c|}{ Prob $>$ chi $2=0.4923$} & \multicolumn{2}{|c|}{ Prob $>$ chi $2=0.1368$} \\
\hline
\end{tabular}


Plot of cumulative sum of squares of recursive residuals (model 1).

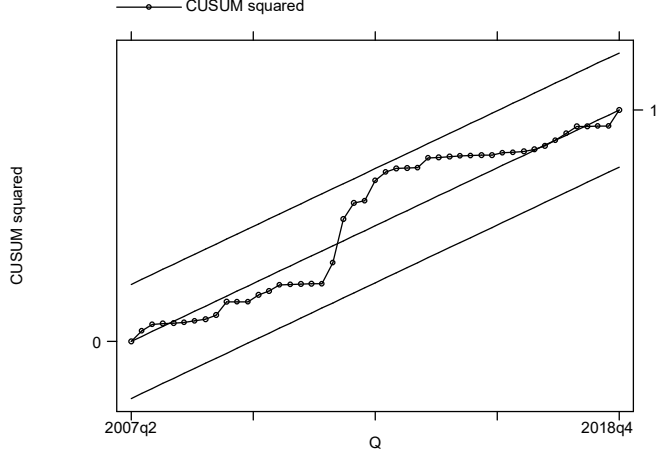

The straight lines represent critical bounds at 5\% significance level.
Plot of cumulative sum of squares of recursive residuals (model 2).

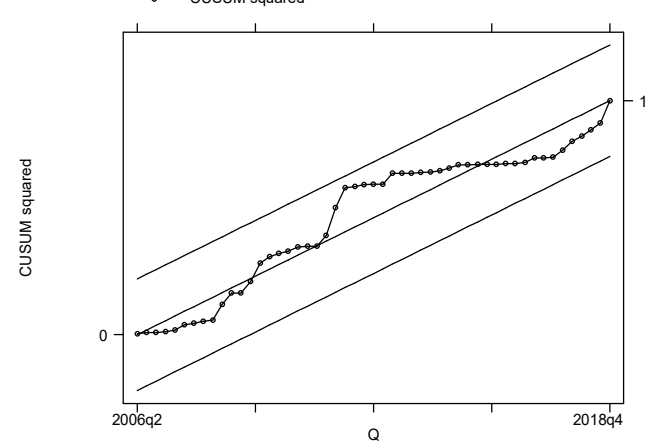

The straight lines represent critical bounds at $5 \%$ significance level.

Fig. 3. Plots of CUSUM squared statistics for coefficient stability tests.

White's test shows that both research models have no homoscedasticity. Simultaneously, Breusch-Godfrey LM test shows that two research models do not have autocorrelation (no serial correlation). In addition, the paper conducted stability tests of the two models through the cumulative sum of squares of recursive residuals (CUSUM squared). The stability test results show that the cumulative sum of squares of recursive residuals is within the standard range at the 5\% significance level (Fig. 3). Therefore, the two research models have stability and appropriateness.

\section{- The impact of the banking system development on the real estate market}

Tables 3 and Table 4 show that the banking system development (measured through the ratio of the domestic credit to the private sector) has a statistically significant impact on the real estate market and the main direction of the impact is positive. Indeed, in the long term, the domestic credit to the private sector (DCP) has a positive impact (0.101) on the real estate market (REM) at the $1 \%$ significance level. In the short term, the domestic credit to the private sector has a positive impact $(0.068)$ on the real estate market at the $10 \%$ significance level. However, with one lag, this direction tends to reverse $(-0.095)$ at the $1 \%$ significance level. This result is consistent with the wealth effect and is found in the studies by Shen et al. (2016) and Lim (2018). This shows that when the banking system increases the credit supply in the economy, the amount of capital that households and enterprises invest in the real estate market will increase, promoting the real estate market.

For the control variables representing the stock market development: The paper found a statistically significant impact of the control variables of the stock market development on the real estate market. Specifically, in both short and long term, the real estate market (REM) is affected positively by the stock index (VNI). Thus, as the stock index increases, the stock value in the investors' portfolio increases. As a result, the investors will increase the demand for housing and invest in the real estate market, which stimulates the real estate market. This result is quite consistent with the views of Markowitz (1952), Kapopoulos and Siokis (2005), Ibrahim (2010), Ding et al. (2014), Lean and Smyth (2014). In addition, the study also found the negative impact of the net transaction value of foreign investors (FI) on the real estate market (REM). This is also appropriate to the reality in Vietnam, where the stock market is still young, the transaction value of foreign investors is limited, and the investments in the real estate market are mainly bank credit. Indeed, the transaction value of foreign investors is relatively small compared to the transaction value in the stock market. Consequently, the stock market development has not had a dramatically positive impact on the real estate market. Fig. 4 shows that the net transaction value of foreign investors increased sharply at the end of 2007, when Vietnam's economy was developing well; meanwhile, the world economy was experiencing many unpredictable changes and started to enter the 
financial crisis. During the period of global financial crisis, foreign investors still tended to transfer capital into Vietnam stock market, but with a reluctant psychology; they mainly held blue-chip stocks in the short term and reduced investments in high-risk stocks. Therefore, in the period of financial crisis, the foreign investors' capital on the stock market lacked stability, even created negative impacts on the stock market (especially when foreign investors implemented the net selling), creating negative impacts on the economy as well as the real estate market in Vietnam.

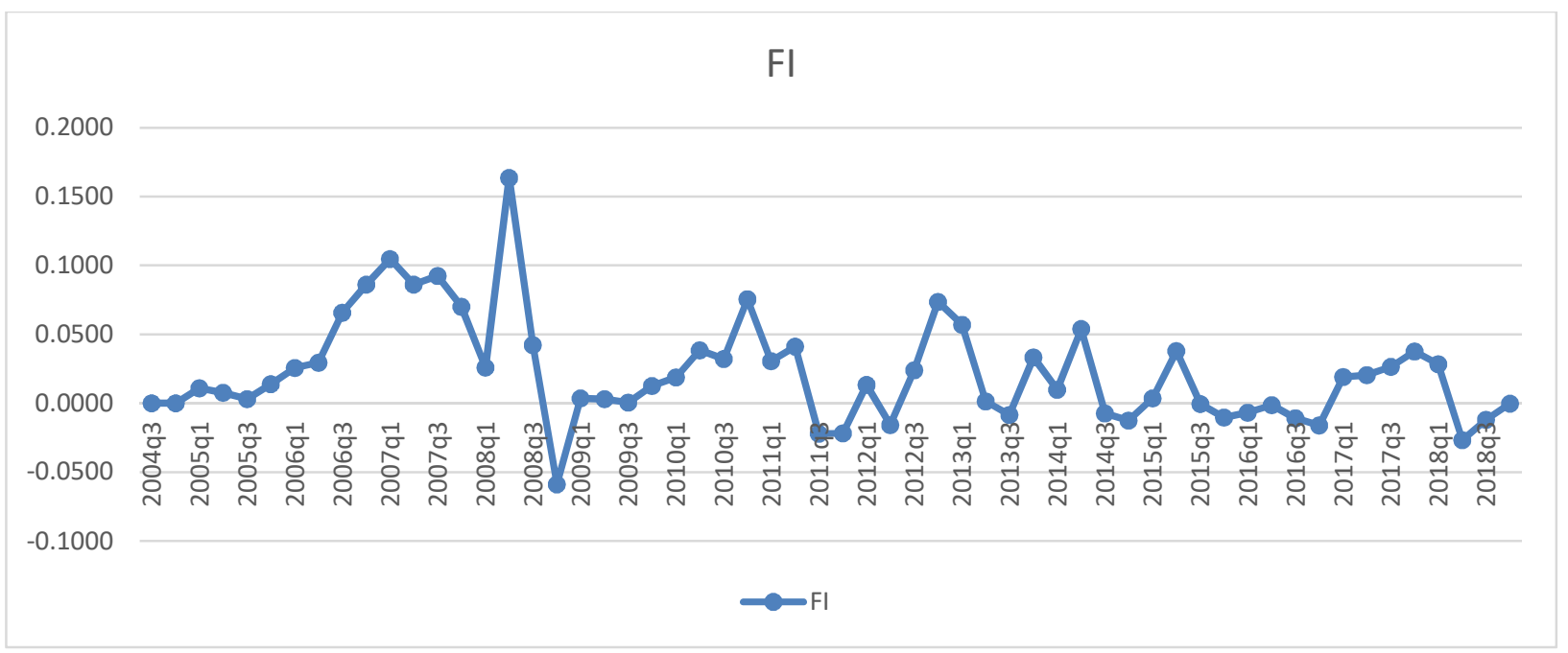

Fig. 4. Net transaction value of foreign investors (FI) in Vietnam (2004:Q3-2018:Q4)

For the control variables representing macroeconomics: in both short and long term, the real estate market is affected positively by the interest rate (IR) and negatively by the global financial crisis (FC). The big difference between the lending interest rate and the deposit interest rate will help increase the income of the banking system, motivate the banking system to develop, and contribute significantly to the development of the real estate market. However, if the difference between the lending interest rate and the deposit interest rate is too big, this is also a warning signal of the risk of a crisis in the banking system, which may lead to the bubble phenomenon on the real estate market. Moreover, the study also found the negative impacts of the global financial crisis on the real estate market in Vietnam. These are the new findings of this paper compared to previous studies.

\section{- The impact of the real estate market on the banking system development}

In both short and long term, the real estate market (REM) has a positive impact on the banking system development (measured through the ratio of the domestic credit index to the private sector - DCP) at the $1 \%$ significance level. This result is consistent with the credit effect and is found in the studies by Shen et al. (2016) and Lim (2018). This shows that when the real estate market develops, real estate holders will easily access loans through mortgaging real estate to borrow money from banks; for this reason, banks will increase the credit supply and profits, contributing significantly to the banking system development. For the control variables representing macroeconomics: in both short and long term, the domestic credit to the private sector (DCP) is affected positively by the economic growth (GDP) and the financial crisis (FC). In addition, the domestic credit to the private sector is also affected negatively by the short-term consumer price index with one lag and two lags. This shows that when the economy develops well and the consumer price index is moderate, the demand for loans will increase and banks will increase the credit supply. For the variable of the financial crisis, when the global financial crisis occurs, banks will limit the lending to the real estate sector and focus more on the lending to the manufacturing sector. Thereby, this will reduce the negative impacts of the global financial crisis on the national economy and contribute to the stability as well as the development of the banking system. When the global financial crisis occurs, if the banking system still increases the credit supply to the areas with high risks, it will 
lead to the risk of the crisis in the banking system, and the fact that the global financial crisis took place in 2007 is considered as a testimony to this impact.

\section{Conclusions and implications}

\subsection{Conclusions}

With the application of the autoregression distributed lag (ARDL) model, the study has shown that a positive relationship existed between the banking system development (measured through the ratio of the domestic credit to the private sector) and the real estate market in Vietnam in both short and long term. In addition, the real estate market is also affected by the stock market development (the stock index and the net transaction value of foreign investors), the interest rate and the global financial crisis. On the other hand, the banking system development is affected by the domestic macroeconomics (the economic growth and the consumer price index) and the global financial crisis. The paper achieved great success when finding the first empirical evidence of the relationship between the banking system development and the real estate market in Vietnam. Moreover, the study also found a statistically significant impact of the global financial crisis on the banking system development and the real estate market in Vietnam, which is a new finding compared to previous studies. Therefore, the research results bring practical and meaningful value to Vietnam. Simultaneously, the research results are the basis to help policy makers and researchers to have a clearer view of the relationship between the banking system development and the real estate market in Vietnam.

\subsection{Implications}

The research results show that the banking system development and the real estate market in Vietnam have a causal relationship. Furthermore, the banking system and the real estate market in Vietnam are also affected by the global financial crisis and the domestic macroeconomics. On this basis, the paper presents some implications as follows:

The Government of Vietnam needs to have policies to stabilize the domestic macroeconomic situation and limit negative impacts from abnormal fluctuations of the world economy. Simultaneously, it is necessary to improve the estimation of the domestic and the world's macroeconomic situation in order to have a basis to apply appropriate policies to promote the banking system development and the real estate market.

For the real estate market, it is essential to build the real estate price index for each geographical region to help policy makers and researchers have a more comprehensive view of the real estate market. Simultaneously, it is requisite to improve the estimation of the real estate market in order to have a sustainable development orientation. In addition, it is necessary to develop a variety of real estate goods in order to meet the actual demands of the market, contribute to overcoming the situation of supply-demand gap in the real estate market, and stabilize the market actively.

The State Bank of Vietnam needs to build a system of information and data about the real estate market, especially attaching importance to the estimation of risks in the real estate market as a source of reference for commercial banks. This information and data system can be managed by an information support center for the real estate market with the same operation method as the Vietnam National Credit Information Center (CIC). Thereby, the State Bank of Vietnam also has a basis to propose policies to develop the banking system and regulate credit flows into the real estate market appropriately.

Commercial banks need to build a system to warn risks of the real estate market. Simultaneously, more attention should be paid for the prevention of credit risks, especially credit for the real estate market. One 
of the reasons leading to the increase in credit risks of the real estate market is due to many limitations in risk estimation and risk prevention in commercial banks.

\section{Limitations and recommendations for future research}

The study achieved certain success when finding a positive relationship between the banking system development and the real estate market in Vietnam, a developing country. Simultaneously, the paper also discovered some new points compared with previous studies. However, the study encountered some limitations, as the data series included in the study were still short due to the characteristics of Vietnam. In addition, Vietnam has no real estate price index; as a result, the research team cannot analyze the fluctuation of the real estate market in terms of price fluctuations. Therefore, it is very necessary to build the real estate price index in Vietnam. This is also an interesting research direction for further studies.

\section{References}

Anundsen, A. K., \& Jansen, E. S. (2013). Self-reinforcing effects between housing prices and credit. Journal of Housing Economics, 22(3), 192-212.

Bahmani-Oskooee, M., \& Ghodsi, S. (2018). Asymmetric causality between the U.S. housing market and its stock market: Evidence from state level data. The Journal of Economic Asymmetries, 18, 1-8.

Batten, J., \& Vo, X.V. (2016). Bank risk shifting and diversification in an emerging market. Risk Management, 18(4), 217-235.

Bolanos, E. R. L., Burneo, K., Galindo, H., \& Berggrun, L. (2015). Emerging Markets Integration in Latin America (MILA) Stock market indicators: Chile, Colombia, and Peru. Journal of Economics, Finance and Administrative Science, 20(39), 74-83.

Cayon, E., Thorp, S., \& Wu, E. (2017). Immunity and infection: Emerging and developed market sovereign spreads over the Global Financial Crisis. Emerging Markets Review, 34, 162-174.

Che, X., Li, B., Guo, K., \& Wang, J. (2011). Property Prices and Bank Lending: Some Evidence from China's Regional Financial Centres. Procedia Computer Science, 4, 1660-1667.

Dickey, D. A., \& Fuller, W. A. (1979). Distribution of the estimators for autoregressive time series with a unit root. Journal of the American Statistical Association, 74(366a), 427-431.

Ding, H., Chong, T. T. L., \& Park, S. Y. (2014). Nonlinear dependence between stock and real estate markets in China. Economics Letters, 124(3), 526-529.

Gasparènienė, L., Remeikienè, R., \& Skuka, A. (2017). Assessment of the impact of macroeconomic factors on housing price level: Lithuanian Case. Intellectual Economics, 10(2), 122-127.

Gimeno, R., \& Martinez-Carrascal, C. (2010). The relationship between house prices and house purchase loans: The Spanish case. Journal of Banking \& Finance, 34(8), 1849-1855.

Godstein, M., Kaminsky, G. L., \& Reinhart, M. (2000). Assessing financial vulnerability, an early warning system for emerging markets. Washington, DC: Institute for International Economics, 1-56.

Hott, C. (2011). Lending behavior and real estate prices. Journal of Banking \& Finance, 35(9), 24292442.

Huang, D., Leung, C., \& Qu, B. (2015). Do bank loans and local amenities explain Chinese urban house prices?. China Economic Review, 34, 19-38.

Hui, E., \& Chan, K. (2014). The global financial crisis: Is there any contagion between real estate and equity markets?. Physica A, 405, 216-225.

Ibrahim, M. H. (2010). House price-stock price relations in Thailand: an empirical analysis. International Journal of Housing Markets and Analysis, 3(1), 69-82.

Ibrahim, M., \& Law, S. (2014). House prices and bank credits in Malaysia: An aggregate and disaggregate analysis. Habitat International, 42, 111-120.

Kaminsky, G. L., \& Reinhart, M. (1999). The twin crises: The causes of banking and balance of payments problems. American Economic Review, 89(3), 473-500.

Kapopoulos, P., \& Siokis, F. (2005). Stock and real estate price in Greece: wealth versus 'credit-price' effect, Applied Economics Letters, 12(2), 125-128. 
Lambertini, L., Mendicino, C., \& Punzi, M. (2017). Expectations-driven cycles in the housing market. Economic Modelling, 60, 297-312.

Lean, H. H., \& Smyth, R. (2014). Dynamic interaction between house prices and stock prices in Malaysia. International Journal of Strategic Property Management, 18(2), 163-177.

Liang, Q., \& Cao, H. (2007). Property prices and bank lending in China. Journal of Asian Economics, $18(1), 63-75$.

Lim, T. (2018). Growth, financial development, and housing booms. Economic Modelling, 69, 91-102.

Markowitz, H. (1952). Portfolio selection. Journal of Finance, 7(1), 77-91.

Pesaran, M., H., Shin, Y., \& Smith, R. (2001). Bounds testing approaches to the analysis of level relationship. Journal of Applied Econometrics, 16(3), 289-326.

Pradhan, R., Arvin, M., Hall, J., \& Bahmani, S. (2014). Causal nexus between economic growth, banking sector development, stock market development, and other macroeconomic variables: The case of ASEAN countries. Review of Financial Economics, 23(4), 155-173.

Shen, C., Lee, Y., Wu, M., \& Guo, N. (2016). Does housing boom lead to credit boom or is it the other way around? The case of China. International Review of Economics and Finance, 42, 349-367.

Tsai, I. (2015). Dynamic information transfer in the United States housing and stock markets. North American Journal of Economics and Finance, 34, 215-230.

Yunus, N. (2012). Modeling Relationships Among Securitized Property Markets, Stock Markets, and Macroeconomic Variables. Journal of Real Estate Research, 34(2), 127-156.

Wen, X., \& He, L. (2015). Housing demand or money supply? A new Keynesian dynamic stochastic general equilibrium model on China's housing market fluctuations. Physica A, 432, 257-268.

Zhang, H., Li, L., Hui, E., \& Li, V. (2016). Comparisons of the relations between housing prices and the macroeconomy in China's first-, second- and third-tier cities. Habitat International, 57, 24-42.

Zhao, S., Zhan, H., Jiang, Y., \& Pan, W. (2017). How big is China's real estate bubble and why hasn't it burst yet?. Land Use Policy, 64, 153-162.

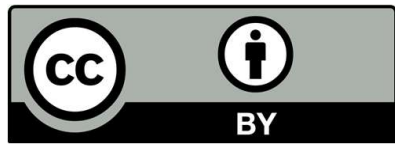

(C) 2020 by the authors; licensee Growing Science, Canada. This is an open access article distributed under the terms and conditions of the Creative Commons Attribution (CCBY) license (http://creativecommons.org/licenses/by/4.0/). 